\title{
An Analysis of Personal Financial Distress: A Review of Financial Behaviors among Rural and Urban Communities
}

\author{
Khaira Amalia Fachrudin, ${ }^{*}$ Siti Latifah ${ }^{2}$ \\ ${ }^{1}$ Faculty of Economic and Business, Unirsitas Sumatera Utara \\ ${ }^{2}$ Forestry Faculty, Universitas Sumatera Utara \\ Email: khaira@usu.ac.id
}

\begin{abstract}
The development is intended to provide welfare to the community and to boost the nation's economy. Financial wellbeing is the state which lies opposite to financial distress. The rural community people in Penyangga village, North Sumatera - Indonesia, have not generated significant income from non-timber forests products and other sources. The present study aims at comparing the financial distress experienced by rural community people of Penyangga village and urban community people of Medan city with relatively similar amount of income. A total of 30 rural people and 30 urban people were involved as the respondents in this study. To observe the difference between financial behavior and financial distress, a discriminant analysis was performed. The test results demonstrated that at alpha five percent, there is no difference in the spending behavior and debt payoff between these two groups. However, there is a significant difference in the financial distress being experienced. Rural community people tend to feel more prosperous with their own financial condition and feel less financially depressed. Despite being financially short and rely solely on rice and vegetables in their neighborhood for food, they live at the constant state of happiness.
\end{abstract}

Keywords: financial behavior, financial distress, rural and urban communities, spending behavior, wellbeing

\section{INTRODUCTION}

Financial prosperity is everyone's dream, however, many are in the state of feeling depressed with their own financial condition. Certain behaviors such as the excessive shopping habit and being in debt might lead to financial distress. Despite having high income, an individual might be facing financial difficulties if his financial behavior is bad particularly during the pandemic. [1] expressed that excessive or unplanned shopping behavior would lead to dissatisfaction with the financial state.

The people in Penyangga village, North Sumatra, Indonesia, make a living out of non-timber forest products as well as from other businesses. To fulfill their food necessities like vegetables, they would pick them out from front yards, things that are rarely done by city people. Most urban people have the habit of buying.

The research carried out [2]. Stress coping) on adolescents in Canada found that even if the economic and social condition are more challenging in rural areas, but the level of stress and ways of copying were found to be similar between rural and urban adolescents.
Research on financial behavior between rural community and urban community was conducted by [3]. It was found that there were no differences in financial behavior between these two groups. The research on saving behavior between the rural and urban communities in Pakistan was carried out by [4], where he found that the savings amount of both groups were equally added up as their income rose.

However, there has been no research conducted on personal financial distress and financial behavior between rural and urban communities in Indonesia. Personal financial distress in the present study encompasses financial prosperity and stress related to personal finances. Whereas the financial behavior referred to in this study is debt behavior and shopping behavior.

Preliminary studies indicated a slight difference where urban community have the tendency to slip into debt to buy non-primary necessities items and tend to spend more on shopping. While the rural community incur debt for the sake of meeting basic needs. Despite the fact that they live within their means such as relying 
on the forests for their needs, they are in the constant state of happiness.

The present study aims at finding empirical evidence of personal financial distress and financial behavior between rural community in Penyangga village and urban community in Medan city with relatively equal amount of income. The research is formulated as : is there any differences in personal financial distress and financial behavior between rural and urban communities? It is therefore of highly importance to conduct this research so as to shed light on why these phenomena happen and ways to overcome them.

\section{METHOD}

The population of the present research is the rural community of Penyangga Village and the urban community of Medan City. A total of 30 rural people and 30 urban people were taken as the sample in this study. The sample of rural people was determined by random sampling method, while the sample of the urban people was determined based on their income level which is equal to that of the rural people.

To observe the difference between financial behavior and financial distress on these two groups, a discriminant analysis was carried out. The variables in the present research include debt behavior $\left(X_{1}\right)$, shopping behavior $\left(\mathrm{X}_{2}\right)$, and personal financial distress that comprises the variables of financial prosperity $\left(\mathrm{X}_{3}\right)$, and personal financial stress $\left(\mathrm{X}_{4}\right)$. The data were collected from questionnaires and interviews to get a clear description of the answers.

\section{FINDINGS AND DISCUSSIONS}

The assumption that must be met in a discriminant analysis is the variance homogeneity. The results of $p$ value statistic of Box's $M$ test shows 0,148 which is greater than alpha $5 \%$, thus the assumption is met.

The canonical correlation value on the Eigen Value table shows 0,442 which if squared would be 0,196 indicating that $19.6 \%$ of the dependent variable variances can be explained by the formed discriminant model.

The significance of Chi Square value on Wilk's Lamba table is of $0,016(<0.05)$ indicating that there is a significant difference in behavior between the rural and urban communities.

Table 1. Test of Equality of Group Means

\begin{tabular}{|c|c|c|c|c|c|}
\hline & $\begin{array}{c}\text { Wilk's } \\
\text { Lamda }\end{array}$ & $\mathrm{F}$ & $\mathrm{df1}$ & $\mathrm{df2}$ & Sig \\
\hline $\mathrm{X}_{1}$ & 0.998 & 0.100 & 1 & 58 & 0.753 \\
\hline $\mathrm{X}_{2}$ & 0.999 & 0.043 & 1 & 58 & 0.837 \\
\hline $\mathrm{X}_{3}$ & 0.860 & 9.469 & 1 & 58 & 0.003 \\
\hline $\mathrm{X}_{4}$ & 0.907 & 5.932 & 1 & 58 & 0.018 \\
\hline
\end{tabular}

Table 1 on the Test of Equality of Group Means shows that the most distinguished significant factors between rural and urban communities is personal financial distress which includes financial improsperity and personal financial stress.

Table 2 on the Structure Matrix shows the variables order that clearly distinguish the behaviors between rural and urban communities.

Table 2. Structure

Matrix

\begin{tabular}{|c|c|}
\hline & Function \\
\cline { 2 - 2 } & 1 \\
\hline $\mathrm{X}_{3}$ & 819 \\
$\mathrm{X}_{4}$ & 648 \\
$\mathrm{X}_{1}$ & 084 \\
$\mathrm{X}_{2}$ & -.055 \\
\hline
\end{tabular}

According to table 2, it is evident that the most distinguished factor between rural community and urban community is personal financial stress which encompasses financial improsperity and personal financial stress. While their debt behavior and shopping behavior show no significant difference.

The income of the rural people and the urban people in this research is relatively equal, yet they show different sense of prosperity and different level of financial stress. This finding is aligned to [5] research which stresses that financial distress is a subjective phenomenon, where individuals in the same situation may differ in their financial stress; and also in line with [6] who asserts that financial distress emerged as a result of of dissatisfaction to one's financial being.

The finding of the present research is also consistent with [7] who conducted a research on the difference of level of happiness between urban and rural communities across the world. A city has many to offer including better quality of life, better job opportunities and infrastructures, yet has higher cost of living, as well as higher pollution and higher exposure to diseases.

\section{CONCLUSIONS}

The test results demonstrated that at alpha five percent, there is no difference in shopping behavior and debt payoff between these two groups. However, there is a significant difference in the level of financial distress experienced. Rural communities tend to feel more prosperous with their own financial condition and are not financially depressed. Irrespective that they are financially short and rely only on the surrounding sources 
of rice and vegetables for food, in fact, they live in happiness.

\section{AUTHORS' CONTRIBUTIONS}

Each author has equal contribution in writing this paper.

\section{ACKNOWLEDGMENTS}

The authors gratefully acknowledged that the present research is funded by Universitas Sumatera Utara Research Institution as per contract Talenta No. 6789/UN5.1.R/PPM/2021, dated June 16, 2021

\section{REFERENCES}

[1] T. K. Hira and O. M. Mugenda, "Predictors of financial satisfaction: Differences between retirees and non-retirees," Journal of Financial Counseling and Planning, vol. 9, no. 2, 1998.

[2] F. J. Elgar, C. Arlett, and R. Groves, "Stress, coping, and behavioural problems among rural and urban adolescents," Journal of Adolescence, vol. 26, no. 5, 2003, doi: 10.1016/s01401971(03)00057-5.

[3] S. Gade and S. Sarma, "Does Financial Literacy Influence Financial Planning? - A Study among Rural and Urban Households," in RSU International Research Conference, 2018, pp. 496-511.

[4] S. e Saqib, S. Panezai, S. Panezai, H. Ullah, U. Ali, and H. Usman, "Determinants of Household Savings in Rural and Urban Areas: The Case of Chitral District, Pakistan," International Journal of Academic Research in Business and Social Sciences, vol. 6, no. 3, 2016, doi: 10.6007/ijarbss/v6-i3/2032.

[5] N. Lajuni, I. Bujang, Abd. A. Karia, and Y. Yacob, "Religiosity, Financial Knowledge, and Financial Behavior Influence on Personal Financial Distress among Millenial Generation," Jurnal Manajemen dan Kewirausahaan, vol. 20, no. 2, 2018, doi: 10.9744/jmk.20.2.92-98.

[6] N. M. Porter and E. Thomas Garman, "Testing a conceptual model of financial well-being," Journal of Financial Counseling and Planning, vol. 4, 1993.

[7] M. J. Burger, phillip S. Morrison, M. Hendriks, and M. M. Hoogerbrugge, "Urban-Rural Happiness Differentials across the World," in The World Happiness Report 2020, 2020. 